\title{
DETERMINANTS OF RESIDENTIAL PER CAPITA WATER DEMAND OF MAKURDI METROPOLIS
}

\author{
M. I. Aho ${ }^{1,}{ }^{*}$, G. D. Akpen ${ }^{2}$ and P. Ivue ${ }^{3}$ \\ 1,2,3 Civil Engineering Department, University of Agriculture, MaKuRdi, Benue State, NiGERIA \\ E-mail addresses: ${ }^{1}$ aho_ped@yahoo.com,2 deliakpen@yahoo.com, ${ }^{3}$ get2peilu@yahoo.co.uk
}

\begin{abstract}
ABSTACT
This report presents the findings of the study on the determinants of residential per capita water demand of Makurdi metropolis in Benue State, Nigeria. Data for the study was obtained by the use of questionnaires, oral interviews and observations. The data was analyzed using SPSS. Twenty variables were considered in the multiple regression analysis for developing a consumption model. Seven variables were found to influence residential per capita water consumption significantly. Level of education, gender, kitchen type, number of cars, and well as a source were positively significant while, household size and number of children below 6 years influence the per capita water demand negatively. The multiple regression analysis showed $R^{2}$ of 0.434 implying that the model explains $43 \%$ of the variation in residential per capital water demand of Makurdi. The $F$ test $(F=14.236, p=0.01)$ showed that the variables in the model combine together to predict the residential per capita water demand of Makurdi metropolis. The consideration of the various factors identified as influencing the residential per capita water consumption in Makurdi metropolis is recommended.
\end{abstract}

Keywords. Residential, per capita water demand, determinants, multiple regression, Makurdi

\section{INTRODUCTION}

Africa may be facing water crisis in the next decade if urgent and deliberate steps are not taken to address the current water problems already manifesting. Studies reported in $[1,2,3]$ revealed that water supply in Nigeria like other developing countries is facing serious challenges many of which are economic, and socio-political in nature. Increase in population over the years in developing countries has made most existing water supply schemes insufficient in meeting the demand. Rapid development has also brought about increase in the uses of water as houses are now with gardens, increased number of cars and water using home appliances. This rapid growth in water demand has to be accompanied by regular review and adjustment in planning, designing and management of water supply systems for the supply to be effective. Reports by intentional bodies like the United Nations (UN) and World Health Organization (WHO) and other non-governmental organizations have indicated that water supply in not always commensurate with demand worldwide. According to [4] only $32 \%$ of rural population in developing countries has access to safe drinking water. Today, a large percentage of the rural population in developing countries continues to live without adequate access to safe and convenient water supply and sanitation [5]. In Nigeria, more than $90 \%$ of rural areas and $60 \%$ of urban areas face water related problems [6].

Makurdi, the capital of Benue state has extensive water resources. It is situated on the banks of River Benue which is one of the two largest rivers in Nigeria. It is expected that with the availability of the river, there should be no scarcity. But only a small fraction of residents have access to pipe born water, households are forced to resort to unsafe alternative sources of water supply from the shallow hand dug wells, which are highly polluted from physical, chemical and bacteriological sources [7].

Many factors contribute to the total water consumed at household level. The presence of household facilities such as low flush toilets, dishwashers and washing machines has been identified as influencing water consumption. Reports in [8-12] used a multiple regression model to study the factors which influence water consumption in Oklahoma City and Tulsa, Oklahoma. The results indicate that average price and per capita income were predictive variables for 
Oklahoma City's water demand, while only per capita income was found to be a predictor for consumption in Tulsa.

The report in [13] investigated the factors contributing to water demand in the peri-urban communities of Awka capital city. Results showed that 13 variables combined to contribute $90.0 \%$ of water demand in the area. In [14] the determinants of residential water demand in Italy was studied and reported that the applied tariff had a negative effect on residential water consumption and that per capita income had a positive effect on water consumption. Among measured climatic and geographical features, precipitation and altitude exerted a strongly significant negative effect on water consumption, while temperature did not influence water demand. This paper, therefore, seeks to determine the relevant factors that influence residential water demand of Makurdi metropolis with a view to developing a model that could be employed for estimating the present level of demand and predicting the future water requirements that can meet the demand of the rapid urbanization of the area.

\section{MATERIALS AND METHODS}

The data for this research was collected using the convenience sampling method from 400households with the use of questionnaires but only data from 393 households was used for the analysis because data from the other 7 households were not reliable. The validity and reliability of the questionnaire was conducted as well as a pretest before its administration. The questionnaire contained questions related to water use and factors that were hypothesized to affect the household per capita water use. The model employed for the analysis of factors affecting residential daily per capita water demand of the households is the multiple regression analysis. Statistical analysis on the observed data was performed using SPSS.

The residential per capita water demand, $\mathrm{Y}$ was modelled as [15]:

$\mathrm{Y}_{1}=\mathrm{B}_{0}+\mathrm{B}_{1} \mathrm{X}_{1}+\mathrm{B}_{2} \mathrm{X}_{2}+\mathrm{B}_{3} \mathrm{X}_{3}+\mathrm{B}_{4} \mathrm{X}_{4}+\mathrm{B}_{5} \mathrm{X}_{5}+\mathrm{B}_{6} \mathrm{X}_{6}$

$+\mathrm{B}_{7} \mathrm{X}_{7} \mathrm{~B}_{8} \mathrm{X}_{8}+\mathrm{B}_{9} \mathrm{X}_{9}+\mathrm{B}_{10} \mathrm{X}_{10}+\mathrm{B}_{11} \mathrm{X}_{11}+\mathrm{B}_{12}$

$\mathrm{X}_{12}+\mathrm{B}_{13} \mathrm{X}_{13}+\mathrm{B}_{14} \mathrm{X}_{14}+\mathrm{B}_{15} \mathrm{X}_{15}+\mathrm{B}_{16} \mathrm{X}_{16}+\mathrm{B}_{17}$

$\mathrm{X}_{17}+\mathrm{B}_{18} \mathrm{X}_{18}+\mathrm{B}_{19} \mathrm{X}_{19}+\mathrm{B}_{20} \mathrm{X}_{20}$

In this case: $\mathrm{Y}_{\mathrm{i}}$ is the Residential daily per capita water demand, $X_{1}$ is the Marital status, $X_{2}$ is the Occupation, $\mathrm{X}_{3}$ is the Level of education, $\mathrm{X}_{4}$ is the Age, $\mathrm{X}_{5}$ is the Gender, $X_{6}$ is the House hold size, $X_{7}$ is the Household location, $\mathrm{X}_{8}$ is the Kitchen type, $\mathrm{X}_{9}$ is the Type of toilet,
$\mathrm{X}_{10}$ is the Number of toilets, $\mathrm{X}_{11}$ is the Bath room type, $\mathrm{X}_{12}$ is the Number of cars. $\mathrm{X}_{13}$ is the Presence of flowers, $X_{14}$ is the Hand dug well as a source, $X_{15}$ is the Bore hole as a source, $\mathrm{X}_{16}$ is the Pipe as a source, $\mathrm{X}_{17}$ is the Vendor / Mairuwa as a source, $\mathrm{X}_{18}$ is the Tanker as a source, $\mathrm{X}_{19}$ is the Sachet as a source. $\mathrm{X}_{20}$ is the Number of children, $\mathrm{B}_{0-20}$ is the Parameter to be estimated.

\section{RESULTS AND DISCUSSION}

Table 1 presents the results on the socio-economic and demographic characteristics of the household respondents. Result on the gender shows that $53.4 \%$ of the household respondents are male and $46.6 \%$ are female.

The age distribution shows that most of the respondents are between 18-44 years, constituting $78.7 \%$ of the sample. This is an indication that majority of those interviewed were adults and so were able to give accurate information on water use.59.0\% were single, $38.2 \%$ married, $5 \%$ divorced and $1.5 \%$ widowed. The high percentage of single respondents could be because the younger persons in the households who are single are usually responsible for fetching and using water so have more accurate information on water use.

Result on level of education of respondent's shows that about $40.7 \%$ are of secondary level, $19.3 \%$ tertiary undergraduate $19.1 \%$ tertiary graduate, $8.7 \%$ primary school, $8.4 \%$ informal education and $3.8 \%$ post graduate. This implies that the respondents were literate enough to understand and give accurate answers to the questions in the questionnaire.

The results on occupation revealed that $43.8 \%$ were students, $28.8 \%$ business persons, $20.4 \%$ civil servants and $6.6 \%$ had other occupations. The high number of student respondents is because the younger persons who are more likely to be students are usually involved in fetching and use of water and were most time selected by members of the household to give the information required.

Result on the number of children $<6$ years present in the households shows that most households who had children in this category had only one $(26.0 \%)$ and the highest number of children in this category present in a household was 5 in $0.5 \%$ of the households.

$45 \%$ of the respondents live in multitenant houses, $27.5 \%$ in flats, $13.0 \%$ in self-contain, $10.0 \%$ in Bungalow, $2.8 \%$ in thatch house and $1.8 \%$ in story building. The major type of house in the study area as 
shown in Table 1 is multitenant house constituting $45 \%$ of the sample. Most households have a household size of 5 persons $(61 \%)$.

The major type of kitchen used is outdoor kitchen (43\%) and kitchens without sink or water supply (20.6\%). Pour flush water supply toilets (67\%) are more common in the area because most houses are not connected to a source. Most households have more of 1 toilet (47.6\%) or 2 toilet (32.8\%). The major types of bathroom seen in the study area are bathrooms with no bath and no tap water (27.0\%), outdoor bathrooms $(24.9 \%)$ and bath without tap water (23.9\%).Most households who own cars have 1 car (28.2\%) and only (30.3\%) of the households have flowers in their houses.

Table 1: Socio-Economic and Demographic Factors of Respondents in Makurdi Metropolis

\begin{tabular}{|c|c|c|c|c|c|}
\hline \multirow[b]{2}{*}{ VARIABLES } & \multirow[b]{2}{*}{ CATEGORY } & \multicolumn{2}{|c|}{ NUMBER OF HOUSEHOLD } & \multirow[b]{2}{*}{ Mean } & \multirow[b]{2}{*}{ Standard deviation } \\
\hline & & $\begin{array}{l}\text { Frequency, } \\
\text { F }\end{array}$ & $\begin{array}{l}\text { Percentage } \\
\%\end{array}$ & & \\
\hline \multirow{3}{*}{ Gender } & Male & 210 & 53.4 & & \\
\hline & Female & 183 & 46.6 & & \\
\hline & Total & 393 & 100 & & \\
\hline \multirow{7}{*}{ Age } & $0-17$ & 50 & 12.7 & & \\
\hline & $18-24$ & 115 & 29.3 & & \\
\hline & $25-34$ & 119 & 30.3 & & \\
\hline & $35-44$ & 75 & 19.1 & & \\
\hline & $45-54$ & 33 & 8.4 & & \\
\hline & 55 and above & 1 & 0.3 & & \\
\hline & Total & 393 & 100 & & \\
\hline \multirow{5}{*}{ Marital Status } & Single & 232 & 59.0 & & \\
\hline & Married & 150 & 38.2 & & \\
\hline & Divorced & 5 & 1.3 & & \\
\hline & Widowed & 6 & 1.5 & & \\
\hline & Total & 393 & 100 & & \\
\hline \multirow{7}{*}{ Education } & Informal Education & 33 & 8.4 & & \\
\hline & Primary School & 34 & 8.7 & & \\
\hline & Secondary School & 160 & 40.7 & & \\
\hline & Tertiary Undergraduate & 76 & 19.3 & & \\
\hline & Tertiary Graduate & 75 & 19.1 & & \\
\hline & Postgraduate & 15 & 3.8 & & \\
\hline & lotal & 393 & 100 & & \\
\hline \multirow{6}{*}{ Occupation } & Student & 172 & 43.8 & & \\
\hline & Civil Servant & 80 & 20.4 & & \\
\hline & Business & 113 & 28.8 & & \\
\hline & Others & 26 & 6.6 & & \\
\hline & No Response & 2 & 0.5 & & \\
\hline & Total & 393 & 100 & & \\
\hline \multirow{7}{*}{ Number of Children ( $<6$ years) } & 0 & 198 & 50.4 & & \\
\hline & 1 & 102 & 26.0 & & \\
\hline & 2 & 73 & 18.6 & & \\
\hline & 3 & 15 & 3.8 & .80 & 977 \\
\hline & 4 & 3 & 0.8 & & \\
\hline & 5 & 2 & 0.5 & & \\
\hline & Total & 393 & 100 & & \\
\hline Household Size & $<5$ & 240 & 61.1 & 5.14 & 3.094 \\
\hline
\end{tabular}




\begin{tabular}{|c|c|c|c|c|c|}
\hline \multirow[b]{2}{*}{ VARIABLES } & \multirow[b]{2}{*}{ CATEGORY } & \multicolumn{2}{|c|}{ NUMBER OF HOUSEHOLD } & \multirow[b]{2}{*}{ Mean } & \multirow[b]{2}{*}{ Standard deviation } \\
\hline & & $\begin{array}{l}\text { Frequency, } \\
\text { F }\end{array}$ & $\begin{array}{l}\text { Percentage } \\
\%\end{array}$ & & \\
\hline & $6-10$ & 136 & 34.6 & & \\
\hline & $11-15$ & 14 & 3.6 & & \\
\hline & 16 and above & 3 & 0.8 & & \\
\hline & Total & 393 & 100 & & \\
\hline \multirow{6}{*}{ Kitchen Type } & Outdoor Kitchen & 169 & 43.0 & & \\
\hline & No sink, no tap water & 81 & 20.6 & & \\
\hline & Sink without tap water & 68 & 17.3 & & \\
\hline & Sink with tap water & 69 & 17.9 & & \\
\hline & No Response & 6 & 1.5 & & \\
\hline & Total & 393 & 100 & & \\
\hline \multirow{4}{*}{ Toilet Type } & Pit & 19 & 4.8 & & \\
\hline & Pour Flush water system & 264 & 67.2 & & \\
\hline & Functional water system & 110 & 28.0 & & \\
\hline & Total & 393 & 100 & & \\
\hline \multirow{6}{*}{ Number of Toilets } & 1 & 187 & 47.6 & \multirow{6}{*}{1.76} & \multirow{6}{*}{0.870} \\
\hline & 2 & 129 & 32.8 & & \\
\hline & 3 & 62 & 15.8 & & \\
\hline & 4 & 14 & 3.6 & & \\
\hline & 5 & 1 & 1.0 & & \\
\hline & Total & 393 & 100 & & \\
\hline \multirow{6}{*}{ Type of Bathroom } & Outdoor & 98 & 24.9 & & \\
\hline & No bath no tap water & 106 & 27.0 & & \\
\hline & Bath without tap water & 94 & 23.9 & & \\
\hline & Bath with tap water & 41 & 10.4 & & \\
\hline & Functional Shower & 54 & 13.7 & & \\
\hline & Total & 393 & 100 & & \\
\hline \multirow{6}{*}{ Number of Cars } & 0 & 206 & 52.4 & \multirow{6}{*}{0.76} & \multirow{6}{*}{0.976} \\
\hline & 1 & 111 & 28.2 & & \\
\hline & 2 & 43 & 11.0 & & \\
\hline & 3 & 30 & 7.6 & & \\
\hline & 4 & 3 & 0.8 & & \\
\hline & Total & 393 & 100 & & \\
\hline \multirow{3}{*}{ Presence of Flowers } & Absent & 274 & 69.7 & & \\
\hline & Present & 119 & 30.3 & & \\
\hline & Total & 393 & 100 & & \\
\hline
\end{tabular}

\subsection{Sources of Water used by Households in the Study Area}

Table 2 shows that most households, about $79.6 \%$ use sachets water. This is water that is packaged in polyethene bags and sold majorly for drinking. $61.3 \%$ use water from hand-dug wells, $51.1 \%$ use water from boreholes, $32.1 \%$ use pipe borne water and only $26.2 \%$ use water from tanks.

The results show that households in the study area use more than one source of water, only a few households have access to pipe borne water and so use water from alternative sources. The major alternative source used by households as seen in
Table2 is hand-dug well, $61.3 \%$. Many households also use water from vendors (mairuwa), 51.7\% and the high number of sachet water uses could be because most households do not have access to potable water and so resort to the use of sachet water for drinking

\subsection{Residential Water Consumption in Makurdi}

Results presented in Table 3 on the residential water consumption for Makurdi metropolises indicate that the major water use is for laundry $146.15 \mathrm{l} / \mathrm{h} / \mathrm{d}$, bathing $90.42 \mathrm{l} / \mathrm{h} / \mathrm{d}$ and flushing $51.95 \mathrm{l} / \mathrm{h} / \mathrm{d}$. This could be because of the hot and dusty weather 
experienced in the area which calls for frequent laundry and increases the frequency of baths per day.

Table 2: Sources of Water used by Households in the Study Area

\begin{tabular}{lcc}
\hline \multirow{1}{*}{$\begin{array}{c}\text { Sources of } \\
\text { Water }\end{array}$} & \multicolumn{2}{c}{$\begin{array}{c}\text { Number of Households indicating } \\
\text { source of water used }\end{array}$} \\
\cline { 2 - 3 } & Frequency & Percentage \\
\hline Hand-dug well & 241 & 61.3 \\
Bore Hole & 138 & 35.1 \\
Pipe Borne & 126 & 32.1 \\
Mai-Ruwa & 203 & 51.7 \\
(Vendor) & 103 & 26.2 \\
Tanker & 313 & 79.6 \\
Sachet & & \\
\hline
\end{tabular}

The mean quantity used for cooking $41.60 \mathrm{l} / \mathrm{h} / \mathrm{d}$ and dishwashing $38.06 \mathrm{l} / \mathrm{h} / \mathrm{d}$ are also gotten majorly from the hand-dug wells and boreholes. $47.6 \%$ of the households sampled own at least a car and use about $35.63 \mathrm{l} / \mathrm{h} / \mathrm{d}$ of water (Table 3) for washing cars at home. The quantity used for cleaning activities 17.65 $\mathrm{l} / \mathrm{h} / \mathrm{d}$ could be because of the many multitenant houses present in the area. These multitenant households usually share toilets, do not have kitchens and the space in the rooms are usually small so do not require much cleaning activities

The quantity used for watering of flowers is 10.28 $\mathrm{l} / \mathrm{h} / \mathrm{d}$. This could be because of the unavailability of water. Most households will rather use their water for other uses than for watering flowers because water is not readily available and others have to buy the water for use. The quantity of water used for cleaning activities by the households reveals the sanitary situation of Makurdi. Though most households use water for cleaning, the quantity used is usually small because of the unavailability of water. The mean residential per capita water demand for Makurdi is estimated as $110.64 \mathrm{l} / \mathrm{c} / \mathrm{d}$ (see Table 3).

\subsection{Determinants of Residential Per Capita Water Demand}

The individual coefficients of factors determining residential per capita water demand shown in Table4 indicate that the unstandardized coefficients of variables like level of education of the respondent (4.850), gender of the respondent (12.167), kitchen type (16.657), number of cars (13.814), and well as a source of water (11.846) were positive and significant $(p \leq 0.1)$. However, variables like household size (-
12.638) and number of children <6years (-7.378) were negative and statistically significant $(\mathrm{p} \leq 0.05)$. The largest Beta (standardized) coefficient was -0.544 which is for household size and the lowest is -0.010 which is for pipe as a source. Other variables like marital status, occupation, household location, toilet type, number of toilets and type of bathroom were not significant. Other insignificant variables were; presence of flowers, borehole as a source, pipe borne as a source, vendors as a source, tanker as a source and sachet as a source.

Table 3: Residential Consumption by Components for

\begin{tabular}{|c|c|c|c|c|c|}
\hline \multicolumn{6}{|c|}{ Makurdi } \\
\hline Uses of water & $\mathrm{N}$ & Minimum & Maximum & Mean & $\begin{array}{l}\text { Std. } \\
\text { Deviation }\end{array}$ \\
\hline Drinking & 393 & .00 & 96.00 & 9.2207 & 8.87303 \\
\hline Flushing & 393 & .00 & 252.00 & 51.9459 & 44.37636 \\
\hline Bathing & 393 & 7.50 & 472.50 & 90.4160 & 63.46251 \\
\hline Cooking & 393 & .00 & 135.00 & 41.6018 & 25.44507 \\
\hline Laundry & 393 & 8.00 & 945.00 & 146.1527 & 106.77466 \\
\hline Dishwashing & 393 & .00 & 150.00 & 38.0623 & 26.00322 \\
\hline Car Washing & 393 & .00 & 420.00 & 35.6336 & 58.59706 \\
\hline $\begin{array}{l}\text { Watering Of } \\
\text { Flowers }\end{array}$ & 393 & 0 & 150 & 10.28 & 23.392 \\
\hline Cleaning & 393 & .0 & 200.0 & 17.650 & 15.2341 \\
\hline $\begin{array}{l}\text { Other } \\
\text { Household }\end{array}$ & 393 & .0 & 75.0 & 4.503 & y.0848 \\
\hline $\begin{array}{l}\text { Water } \\
\text { Consumption }\end{array}$ & 393 & 61.75 & 1369.00 & 445.4656 & 212.67590 \\
\hline $\begin{array}{l}\text { Per Capita } \\
\text { Water }\end{array}$ & 393 & 27.20 & 467.50 & 110.6437 & 71.87002 \\
\hline $\begin{array}{l}\text { Demand } \\
\text { Valid N } \\
\text { (Listwise) }\end{array}$ & 393 & & & & \\
\hline
\end{tabular}

Source: Computed from Field Data

\subsection{Multiple Regression Analysis for Variables Influencing Per Capita Water Consumption}

In multiple models, the unstandardized coefficient is the impact of a one-unit increase in an independent variable on dependent variable, holding constant the other independent variables. The analysis of the coefficient of variables presented in Table 1 showed that level of education influences the RPCWD positively and has a $5 \%$ level of significance. This implies that respondents with higher level of education reported more water consumption than those with lower level of education. This agrees with findings by [16]. Specifically, an increase in one level of education of the respondent is likely to increase RPCWD by 4.85 litres. Paper [17] also indicated that literacy level has influence on domestic water use. 
This influence could be because those who are more educated are more likely to have more modernized style of living. Modernized style of living consumes more water because of the use of en suit rooms, utilizing new machinery for washing and cleaning, and having frequent faucets inside and outside bathrooms and kitchens to facilitate cleaning activities [18]. The variance could also be because those with higher level of education seem to be more sensitive to the health implication of water consumed, so are more likely to use more water for sanitary purposes [19].

Table 4: Table of Coefficients for factors determining residential per capita water demand

\begin{tabular}{|c|c|c|c|c|c|}
\hline \multirow{2}{*}{ Model } & \multicolumn{2}{|c|}{$\begin{array}{l}\text { Unstandardized } \\
\text { Coefficients }\end{array}$} & \multirow{2}{*}{$\begin{array}{c}\begin{array}{c}\text { Standardized } \\
\text { Coefficients }\end{array} \\
\text { Beta }\end{array}$} & \multirow{2}{*}{$t$} & \multirow{2}{*}{ Sig. } \\
\hline & B & $\begin{array}{l}\text { Std. } \\
\text { Error }\end{array}$ & & & \\
\hline (Constant) & 139.365 & 18.928 & & $7.363^{*}$ & .000 \\
\hline $\begin{array}{l}\text { Marital } \\
\text { status }\end{array}$ & 3.540 & 6.427 & .024 & .551 & .582 \\
\hline occupation & -7.113 & 7.953 & -.040 & -.894 & .372 \\
\hline education & 4.850 & 2.371 & .097 & $2.046^{\star \star}$ & .041 \\
\hline Age & -.977 & 2.735 & -.016 & -.357 & .721 \\
\hline Gender & 12.167 & 6.683 & .085 & $1.821^{* \star *}$ & .069 \\
\hline $\begin{array}{l}\text { Household } \\
\text { size }\end{array}$ & -12.638 & 1.070 & -.544 & $-11.816^{*}$ & .000 \\
\hline $\begin{array}{l}\text { Household } \\
\text { location }\end{array}$ & -1.580 & 3.548 & -.024 & -.445 & .656 \\
\hline $\begin{array}{l}\text { Kitchen } \\
\text { type }\end{array}$ & 16.657 & 8.399 & .111 & $1.983^{\star *}$ & .048 \\
\hline Toilet type & -6.203 & 8.202 & -.041 & -.756 & .450 \\
\hline $\begin{array}{l}\text { Number of } \\
\text { toilets }\end{array}$ & -6.378 & 4.384 & -.077 & -1.455 & .147 \\
\hline Bath type & 10.861 & 10.219 & .065 & 1.063 & .289 \\
\hline $\begin{array}{l}\text { Number of } \\
\text { cars }\end{array}$ & 13.814 & 4.144 & .188 & $3.333^{*}$ & .001 \\
\hline $\begin{array}{l}\text { Presence } \\
\text { of flowers }\end{array}$ & 8.537 & 7.900 & .055 & 1.081 & .281 \\
\hline Well & 11.846 & 6.529 & .080 & $1.815^{* * *}$ & .070 \\
\hline borehole & 2.258 & 7.691 & .015 & .294 & .769 \\
\hline pipe & -1.498 & 6.635 & -.010 & -.226 & .821 \\
\hline $\begin{array}{l}\text { Mairuwa } \\
\text { (vendor) }\end{array}$ & 9.605 & 7.336 & .067 & 1.309 & .191 \\
\hline tanker & 10.208 & 7.078 & .063 & 1.442 & .150 \\
\hline Sachet & 4.889 & 7.609 & .028 & .643 & .521 \\
\hline $\begin{array}{l}\text { Number of } \\
\text { children }\end{array}$ & -7.378 & 3.283 & -.100 & $-2.248^{\star *}$ & .025 \\
\hline
\end{tabular}

Source: SPSS Generated Table

a. Dependent Variable: Residential per capita water demand (consumption)

${ }^{*},{ }^{* *},{ }^{* *}=$ t-ratio significant at $1 \%, 5 \%$ and $10 \%$ level respectively

The variable gender was positive and significant at $10 \%$ level. This indicates that female respondents reported more water use than male. This agrees with [16]. The value of the unstandardized beta of 12.167 implies that households with female respondents indicated the use of 12.167litres more RPCWD than households whose respondents were male. This could be because most water using activities are carried out by the female in the households.

Household size has an unstandardized coefficient of 12.638 , which is negative and significant at $1 \%$ level. This implies that increase in household size by one person will decrease the RPCWD by 12.638 litres.This is similar to findings by [18] who stated that the small number of persons in the house leads to higher rate of water consumption per person since some fixed activities such as watering of flowers and cleaning of the house are not dependent on the number of persons in the household. [11] also found that consumption decrease with increase in household size.

The kitchen type used by the household is positively related to the RPCWD at 5\% level. This implies that, households with kitchens connected to water supply indicated the use of more water than households whose kitchens were not connected to a source. The result shows that specifically, households with connected kitchens (sink with functional tap) use 16.657litres more water than the unconnected ones. [20] also found that connectivity to water source increases water use.

The number of cars owned by households has an unstandardized beta coefficient of 13.814. It influences RPCWD positively and is significant at $1 \%$ level. This implies that an increase in the number of cars in a household by one will increase the RPCWD by 13.814litres.The ownership of cars by a household could be an indication that the household has a high standard. Most households who indicated the ownership of cars also indicated the use of water for washing of cars. This shows that cars are washed at home and will increase the water consumption. Therefore, households with cars will use more water than households without cars.

Hand dug well as a source used by households was positively related to RPCWD and significant at $10 \%$ level. The unstandardized beta coefficient was 11.846 which implies that households who use well as a source indicated the use of 11.846litres more water than households who did not indicate the use of well as a source. Results revealed that $61.1 \%$ of the sampled households use well as a source, also many households indicated the use of well water for cooking 
and other purposes apart from drinking. This shows that households prefer well as an alternative source and preference of a water source is found to influence domestic water use [21].

The variable, number of children less than 6years had a level of significance of $5 \%$ and was found to influence the RPCWD negatively. The value of the unstandardized coefficient -7.378 implies that an increase in the number of children below 6years will decrease the RPCWD by 7.378litres. This could be because the quantity of water required by children in this age group for drinking, bathing, etc. is small compared to older persons. This is similar to findings by [16] who found that the higher the age, the more demand for water. The variance could also be because children <6yrs will most likely not participate in fetching water which is similar to findings by [21] that households dominated by young adults are more likely to have more supply of water than those dominated by aged or children of less than school age. Thestandardized coefficient $\beta$ values can be used in comparing the contribution of each predictor (independent variables). The largest $\beta$ coefficient of0.544 is for household size. This means that this variable makes the strongest unique contribution to explaining the dependent variable, when the variance explained by all other variables in the model is controlled. The $\beta$ value for pipe as a source was 0.010 which made the least contribution.

\subsection{Modeling of Residential Per Capita Water Demand}

The model Summary presented in Table 5 shows the result of multiple regression analysis. The multiple correlation coefficient $\mathrm{R}$ was obtained to be 0.658 , coefficient of determination $\mathrm{R}^{2}$ was 0.434 , adjusted $\mathrm{R}^{2}=0.403$ and the standard error of the estimate was 55.52664.The value of the $\mathrm{R}^{2}$ indicates how much of the variance in the dependent variable Residential per capita water consumption (RPCWD) is explained by the model. The $\mathrm{R}^{2}$ of 0.434 presented in Table 5 implies that about $43 \%$ of the variation in RPCWD is explained by the model. According to the guidelines provided in [22], this is an expected result for household-level cross-sectional data.

\subsection{Significance of the Regression Model}

The result of the F-test is presented in Table 6. The Analysis of variance (ANOVA) result tests the null hypothesis that the socioeconomic and demographic factors do not significantly influence the residential per capita water demand of Makurdi. The F-test gave a value of 14.236 which was significant at $1 \%$. The significant $\mathrm{F}$-test $(\mathrm{F}=14.236, \mathrm{P}=0.01)$ implies that the independent variables used in the model as determinants of RPCWD jointly influence the RPCWD of Makurdi metropolis.

Table 5: Model 1 Summary

\begin{tabular}{|c|r|c|c|}
\hline $\mathrm{R}$ & $\begin{array}{c}\mathrm{R} \\
\text { Square }\end{array}$ & $\begin{array}{c}\text { Adjusted R } \\
\text { Square }\end{array}$ & $\begin{array}{c}\text { Std. Error of the } \\
\text { Estimate }\end{array}$ \\
\hline $0.658^{\mathrm{a}}$ & 0.434 & 0.403 & 55.52664 \\
\hline \multicolumn{3}{|c|}{ Source: SPSS Generated Table }
\end{tabular}

a. Predictors: (Constant), number of children, kitchen type, marital status, well, tanker, sachet water, age, pipe, gender, household size, occupation, borehole, presence of flowers, level education, mairuwa, number of toilets, toilet type, household location, number of cars, bathroom type.

Table 6: ANOVA Results to show Significance of the Model

\begin{tabular}{llllll}
\hline & Sum of Squares & Df & Mean Square & F & Sig. \\
\hline Regression & 877844.403 & 20 & 43892.220 & 14.236 & $.000^{\mathrm{b}}$ \\
Residual & 1146953.142 & 372 & 3083.207 & & \\
Total & 2024797.545 & 392 & & & \\
\hline
\end{tabular}

Source: SPSS Generated Table

a. Dependent Variable: Per capita water demand

b. Predictors: (Constant), number of children, kitchen type, marital status, well, tanker, sachet, age, pipe, gender, household size, occupation, borehole, presence of flowers, education, mairuwa, number of toilets, toilet type, household location, number of cars, bathroom type.

\subsection{The Regression Model}

The Regression Model developed for estimation and forecasting of Residential per Capita Water Demand (RPCWD) is shown below;

$$
\begin{aligned}
\mathrm{Y}= & 139.365+4.850 \mathrm{EDU}+12.167 \mathrm{GEN}-12.638 \mathrm{HHS} \\
& +16.657 \mathrm{KTY}+13.814 \mathrm{NCR}+11.846 \mathrm{WS}- \\
& \text { 7.378NCH }
\end{aligned}
$$

In (2), $\mathrm{Y}$ is the Residential Per Capita Water Demand, EDU is the Level of Education, GEN is the Gender, HHS is the Household Size, KTY is the Kitchen Type, NCR is the Number of Cars, WS is the Hand dug well as Source, NCH is the Number of Children $<6$ years, This shows that when all the variables in the model are not different from zero, the RPCWD will be 139.365 litres.

\section{CONCLUSION AND RECOMMENDATIONS}

The study on the determinants of residential per capita water demand of Makurdi metropolis in Benue State of Nigeria has been carried out. The multiple regression analysis showed that $43 \%$ of the variation in the residential per capita water demand is explained by the model generated and the $\mathrm{F}$ test indicates that the variables in the model namely; level of education, gender, house hold size, kitchen type, 
number of cars, hand dug well as source and number of children $\leq 6$ years combine together to predict the residential per capita water demand of Makurdi. It was recommended that the variables identified as influencing residential per capita water demand in Makurdi should be considered when planning water supply. Also, other studies on agricultural, industrial and commercial water demand should be done to estimate the total per capita water demand of Makurdi.

\section{REFERENCES}

[1] Shiklomanov, I. A.. Appraisal and Assessment of World Water Resource Water International, 25(1), 2002, pp 11-32.

[2] Alayande, A. W. Water Demand Management. Paper presented at a workshop titled: Urban Water Supply Facilities Maintenance held at National Water Resources Institute, Kaduna Nigeria, November $7^{\text {th }}-18^{\text {th }} 2005$.

[3] Emoabina, I. V. Water Demand Management: Prospects and Prospective of Implementation in Nigeria, Proceedings of International Congress on River Basin Management. Ibadan, October 23-26, 2006, 88: pp 154-159

[4] WHO Water and Sanitation Update 2010. 20 Avenue Appia, 1211 Geneva 27, Switzerl and: WHO Press.

[5] Dada, A. C.. Sachet Water Phenomenon in Nigeria: Assessment of the Potential Health Impacts, African Journal of Microbiology Research 3 (1), 2009, pp 015-021.

[6] ADF.. Rural Water Supply and Sanitation Subprogrammes in Yobe and Osun States of NigeriaAppraisal report. African Development Fund, Water and Sanitation Department (OWAS), May, 2007.

[7] Mile, I.I., Dagba, B.I., and Jande, J.A., Iron Contamination of Shallow Wells in Makurdi Urban Area, Benue State, Nigeria. Pak. J. Chem., 2, 2012, pp 1-3.

[8] Malla, P. B. and Gopalakrishnan, C.. Residential Water Demand in a Fast-Growing Metropolis: The Case of Honolulu, Hawaii. Water Resources Development, 13(1), 1997, pp 35-51.

[9] Arubes, F., Garcia-Valĩnas, M. A. and Mart'inezEspĩneira R. Estimation of Residential Water Demand: A State-of-the-Art Review. Journal of Socio-Economics, 32, 2003, pp 81-102.
[10] Domene, E. and Saurí, D.. Urbanization and Water Consumption: Influencing Factors in the Metropolitan Region of Barcelona. Urban Stud. 43, 2006, pp 1605-1623.

[11] Hall, M.J., Hooper, B.D. and Postel, S.M.. Domestic Per Capita Water Consumption in South West England J. Iwem, 198, pp 62-63

[12] Richard, C. and Arthur, C.. Municipal Water Demand Study of Oklahoma city and Tulsa Oklahoma, Oklahoma Water Resource Board, Tulsa office. Oklahoma, 1984.

[13] Ezenwaji, E. E., Phil-Eze, P.O., Otti, V. I. and Eduputa, B. M. Household Water Demand in the Peri-Urban Communities of Awka, Capita of Anambra State, Nigeria Journal of Geography and Regional Planning , 6(6), 2013, pp 237-243,

[14] Romano, G., Salvati, N and Guerrini, A. Estimating the Determinants of Residential Water Demand in Italy.Retrieved at www.mdpi.com/journal/water on 29th April, 2015.

[15] Zhang, H. H., and Brown, D. F. Understanding Urban Residential Water Use in Beijing and Tianjin, China. Habitat International, 29, 2005, pp 469-491.

[16] Anyashola, A. M., Sule, B. F., and Salami, A. M., Modelling of Residential Water Demand at Household Level in Ilorin, Nigeria, .J. Res. Information in Civ. Engr. 7(1), 2010, pp 59-67

[17] Ifabiyi, I. P..Willingness to Pay for Water at Household Level in Ilorin, Kwara State, Nigeria. Global J. Human Soc. Sci., 11(2), 2011, pp 14 - 24.

[18] Almotirin, F. A. and Falah, M. W. The Influence of Water and Sewage Networks on Residential Water Consumption. Int.Journal Water Resources and Environment Engr. 4(2), 2010, pp.103-106.

[19] Fotue L. A. T. and Sikod, F., Determinants of the Households Choice of Drinking Water Source in Cameroun. Journal of Sustainable Development in Africa, 7(3), 2012, pp 86 - 97.

[20] Ukata, C. U., Ohon, E. O., Ndik, E. J., Eze, E.E., and Ibor, U.U.. Cost Analysis of Domestic Water Consumption in Calabar Metropolis, Cross River State, Nigeria J. Hum Ecol, 2011,36 (3),pp 199-203.

[21] Ogunbode, T. 0 and Ifabiyi, P. I., Determinants of Domestic Water Consumption in a Growing Urban Centre in Osun State, Nigeria. African Journal of Environmental Science and Technology. 8(4), 2014, pp 247- 255.

[22] Pallant, J.. A Step by Step Guide to Data Analysis using the SPSS Program, SPSS Survival Manual (4th edition), International Bestseller, Open University Press, 2010, McGraw-Hill Education. 